\title{
Transfer of plasmid DNA to Brevibacterium lactofermentum by electrotransformation
}

\author{
Sylvie Bonnassie, ${ }^{1}$ Jean-François Burini, ${ }^{2}$ Jacqueline Oreglia, ${ }^{1}$ Annie Trautwetter, ${ }^{3}$ \\ Jean-Claude Patte ${ }^{4}$ and A. Michel Sicard ${ }^{1 *}$ \\ ${ }^{1}$ Centre de Recherche de Biochimie et de Génétique Cellulaires du CNRS, 118 route de Narbonne, \\ 31062 Toulouse cédex, France \\ ${ }^{2}$ Laboratoire de Microbiologie du Froid, Institut Universitaire de Technologie, 43 rue Saint-Germain, \\ 27000 Evreux, France \\ ${ }^{3}$ Laboratoire de Génétique et Physiologie Microbiennes, Campus de Beaulieu, avenue du Général Leclerc, \\ 35042 Rennes, France \\ ${ }^{4}$ Laboratoire de Chimie Bactérienne du CNRS, 31 chemin Aiguier, 13402 Marseille Cédex 9, France
}

(Received 29 January 1990; revised 8 May 1990; accepted 17 July 1990)

\begin{abstract}
The Escherichia coli-Brevibacterium lactofermentum shuttle vector pBLA was introduced into intact cells of $B$. lactofermentum by electrotransformation. Several parameters of this procedure such as voltage and cell concentration were analysed. Optimal conditions gave an efficiency of $10^{6}$ transformants per $\mu \mathrm{g}$ of DNA. Two recalcitrant strains could be electrotransformed when an ampicillin pretreatment step was used. Electrotransformation experiments using DNAase or different structural forms of plasmid DNA showed that the electrotransformation process is quite different from natural transformation involving competence development. Restriction-modification-proficient $B$. lactofermentum could be efficiently electrotransformed with pBLA DNA isolated from $E$. coli. This restriction-modification system therefore seems to be overcome by electrotransformation. Thus electrotransformation may efficiently replace the protoplast bacterial transformation method.
\end{abstract}

\section{Introduction}

Molecular genetics has undergone a tremendous development as a result of the discovery of novel systems for the exchange of genetic material. The first system to be discovered was DNA-induced natural bacterial transformation in Streptococcus pneumoniae (Avery et al., 1944). The number of naturally transformable strains being small, several other techniques have been devised to introduce DNA into bacteria. The discovery of penetration of DNA into Escherichia coli cells by Mandel \& Higa (1970) opened the field of genetic engineering. However, this procedure is inefficient for the majority of bacteria. Protoplast transformation is much more generally applicable to most genera (Bibb et al., 1978; Chang \& Cohen, 1979; Katsumata et al., 1984), but it is difficult to establish the best conditions for transformation, and the method is often not reproducible. Moreover, these methods have been hampered by inconsistency, the time taken for the procedure and the low efficiency of transformation. DNA uptake by electrotransformation seems to be a much more general system (see Chassy et al., 1988, for a review), although some strains are recalcitrant to electrotransformation (Chassy et al., 1988; Wirth et al., 1989). As genetic engineering requires the transformation of a variety of strains, it is important to develop a procedure to overcome these difficulties. We report here the plasmid electrotransformation of an amino acid producer, Brevibacterium lactofermentum, which we have previously transfected and transformed by the protoplast method (Yeh et al., 1985, 1986), and we describe a protocol that allows electrotransformation of strains that were previously untransformable.

\section{Methods}

Bacterial strains and growth conditions. Electrotransformation experiments were performed with three strains of $B$. lactofermentum. Strains 15 and 10 were isolated as restriction-modification mutants of strain 180 (Bonnassie et al., 1990), which is a rifampicin-resistant derivative of $B$. lactofermentum A TCC 21086 . They were grown in Luria-Bertani (LB) medium (Maniatis et al., 1982) at $34^{\circ} \mathrm{C}$, with shaking. For the preparation of agar plates, Bacto-agar (Difco) was added to a final concentration of $1.5 \%(\mathrm{w} / \mathrm{v})$. Media for selection and subsequent growth of transformants contained $20 \mu \mathrm{g}$ kanamycin sulphate $\mathrm{ml}^{-1}$ 
(Sigma). E. coli $\mathrm{AB} 1157$ (F- $\mathrm{F}^{-}$hr-1 ara-14 leuB6 $\Delta$ (gpt-proA)62 lacY1 tsx33 supE44 galK2 $\lambda^{-}$rac hisG4(Oc) rfbD1 mgl-51 rpsL31 kdgK51 xyl-5 $m t l-1$ arg $E 3$ thi-1), derived from $E$. coli $\mathrm{K} 12$, was used for plasmid DNA preparation in order to test for restriction in $B$. lactofermentum.

Plasmid isolation. Large-scale preparation of plasmid DNA from $B$. lactofermentum was done by the method of Yeh et al. (1986) and from $E$. coli AB1 157 according to Ish-Horowicz \& Burke (1981). Plasmids were purified by $\mathrm{CsCl} /$ ethidium bromide density-gradient centrifugation and stored in water. DNA concentrations were determined by measuring absorbance at $260 \mathrm{~nm}$.

Purification of plasmid DNA by electroelution. All restriction enzymes were obtained from BRL and were used as recommended by the supplier. Plasmid DNA fragments were analysed by $0.8 \%$ agarose gel electrophoresis (Maniatis et al., 1982) and purified by electroelution with the IBI Unidirectional and Analytical Electroeluter system. $\lambda$ DNA cut by HindIII, which was purchased from Boehringer Mannheim, was used as a molecular mass marker and as a DNA concentration reference.

Electrotransformation procedures. For electrotransformation with the Gene Pulser apparatus from Bio-Rad, cells were grown in LB medium to an $\mathrm{OD}_{540}$ of $0 \cdot 3-0.5$ and harvested by centrifugation. Cells were then washed twice in phosphate/sucrose electroporation buffer (PSB: 7 mMpotassium phosphate $\mathrm{pH} 7.5,0.5 \mathrm{M}$-sucrose, $1 \mathrm{mM}-\mathrm{MgCl}_{2}$ ) and concentrated in $0.8 \mathrm{ml}$ PSB $\left(2-5 \times 10^{8}\right.$ c.f.u. $\left.\mathrm{ml}^{-1}\right)$. Unless otherwise indicated, transformation was carried out with $500 \mathrm{ng}$ plasmid DNA per assay, which gave a DNA concentration of $625 \mathrm{ng} \mathrm{ml}^{-1}$. With the Pulse Controller apparatus, $40 \mu \mathrm{l}$ of cells (about $7 \times 10^{8} \mathrm{c}$.f.u. $\mathrm{ml}^{-1}$ ) was mixed with $37.5 \mathrm{ng}$ of plasmid DNA $\left(937.5 \mathrm{ng} \mathrm{ml}^{-1}\right)$. Cells were kept on ice for $10 \mathrm{~min}$ before and after the electric pulses.

Electrotransformation with the gene pulser apparatus from Jouan Laboratories was performed using cells washed three times in Tris/sucrose electroporation buffer (TSB: $10 \mathrm{~mm}$-Tris/ $\mathrm{HCl} \mathrm{pH} \mathrm{7.5,}$ $270 \mathrm{~mm}$-sucrose, $0.5 \mathrm{~mm}-\mathrm{MgCl}_{2}$ ). About $10^{8}$ cells were mixed with $75 \mathrm{ng}$ of pBLA into a final volume of $18 \mu \mathrm{l}$ and immediately transferred into the sterile electrode chamber for the pulse. Cells were at once diluted in LB medium for expression before selection.

\section{Results}

Construction of the B. lactofermentum-E. coli shuttle vector $p B L A$

The plasmid used for electrotransformation was the $10 \cdot 1 \mathrm{~kb}$ B. lactofermentum-E. coli shuttle vector pBLA. It was obtained by cloning the $5.6 \mathrm{~kb}$ HindIII fragment of pAT21.1 (obtained from P. Courvalin: Trieu-Cuot \& Courvalin, 1983), which carries an Enterococcus faecalis gene encoding kanamycin resistance and the ampicillin resistance gene from transposon $\mathrm{Tn} 3$, into the HindIII site of pBLl (a $4.4 \mathrm{~kb}$ plasmid isolated from a $B$. lactofermentum strain, which was obtained from $\mathrm{A}$. Deschamp) (Fig. 1). As observed for Corynebacterium glutamicum (Ozaki et al., 1984), the ampicillin resistance gene does not allow the phenotypic selection of $B$. lactofermentum transformants.

\section{Effect of voltage on survival and transformation frequency}

For this study we used B. lactofermentum strain 15, which is a restriction- and modification-deficient derivative of $B$. lactofermentum 180 . To determine suitable conditions for electrotransformation of $B$. lactofermentum 15 , we examined the effect of the initial electric field strength on transformation frequency and survival.

For field strengths of 3.25 to $5 \mathrm{kV} \mathrm{cm}{ }^{-1}$, the transformation frequency (transformants per viable cell) increased up to $1.4 \times 10^{-4}$ (Fig. $2 a$ ). Within the range 5 to $6.25 \mathrm{kV} \mathrm{cm}^{-1}$ (the latter is the maximum that can be obtained by the Bio-Rad Gene Pulser unit) the transformation frequency remained essentially constant. No cell death was observed (data not shown). The DNA concentration used in these experiments was $625 \mathrm{ng} \mathrm{ml}^{-1}$. As the number of transformants is proportional to DNA concentration up to more than $1 \mu \mathrm{g} \mathrm{ml}^{-1}$ (Bonnassie et al., 1989), the transformation efficiency can be evaluated as $4.8 \times 10^{4}$ per $\mu \mathrm{g}$ DNA. Field strengths greater than $6.25 \mathrm{kV} \mathrm{cm}^{-1}$, obtained with the Pulse Controller unit, produced a significant decrease in transformation frequency and survival fell to $44 \%$ at $12.5 \mathrm{kV} \mathrm{cm}^{-1}$ (Fig. $2 b$ ).

The experiments described above were done using exponential decay voltage pulses (Bio-Rad system). We also used the Jouan apparatus to provide square wave pulses, which allows control of physical parameters such as pulse duration. We used two field strengths (4.7 and $\left.5 \cdot 3 \mathrm{kV} \mathrm{cm}^{-1}\right)$ and pulse durations of $3,5,7$ and $10 \mathrm{~ms}$. The highest transformation frequency was $2.8 \times 10^{-5}$ transformants per viable cell and occurred at a field strength of $4.7 \mathrm{kV} \mathrm{cm}^{-1}$ and a pulse duration of $10 \mathrm{~ms}$. The frequencies obtained in the other treatments differed at most by a factor of three (data not shown).

\section{Effect of cell concentration}

In the preceding experiments a cell concentration of $2 \times 10^{8}$ c.f.u. $\mathrm{ml}^{-1}$ was arbitrarily chosen. However, the yield of transformants might be increased with an increase in the number of cells present when the DNA concentration is held constant, as reported for electrotransformation of E. coli (Dower et al., 1988). Using the same amount of DNA (500 ng), we tested this expectation (Table 1). High cell concentrations increased the number of transformants. Although the transformation frequency was nearly constant, due to the linear response between transformants and cell concentration, the use of a higher cell concentration $\left(3 \times 10^{9}\right.$ c.f.u. $\left.\mathrm{ml}^{-1}\right)$ increased the transformation efficiency to $8 \times 10^{5}$ transformants per $\mu \mathrm{g}$ of DNA. These results are in agreement with experiments reported by Wolf et al. (1989) and Bonamy et al. (1990) on Corynebacterium glutamicum. 

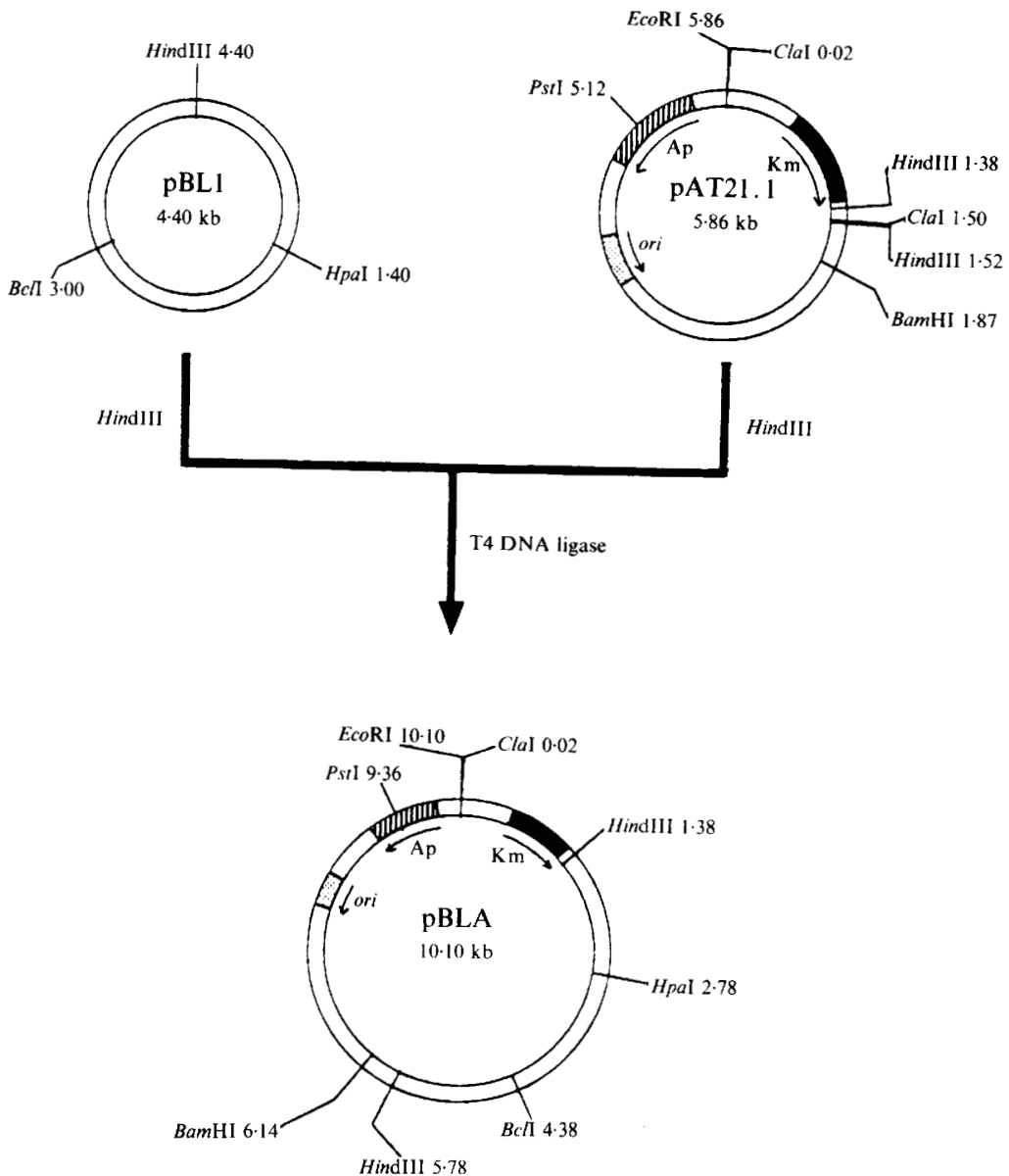

Fig. 1. Construction of the pBLA B. lactofermentum-E. coli shuttle vector. This plasmid was constructed from pBLl (B. lactofermentum plasmid) and pAT21.1 (E. coli plasmid). Ap and $\mathrm{Km}$ signify the genes for ampicillin and kanamycin resistance respectively.
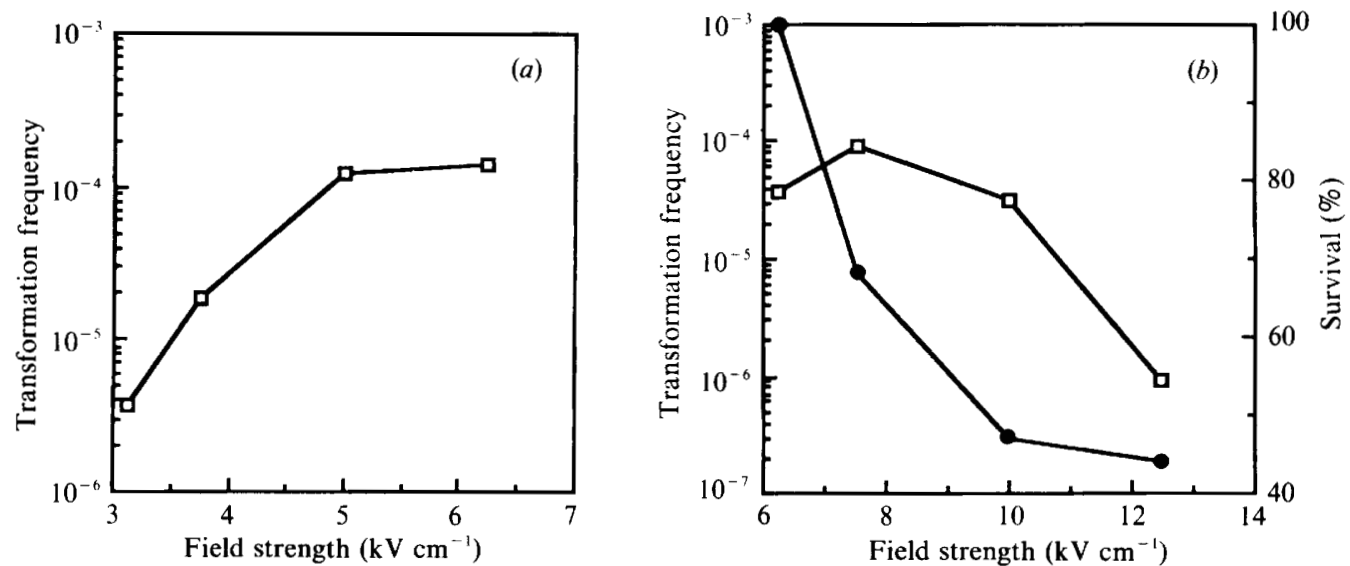

Fig. 2. Effect of field strength on transformation frequency. Cell suspension of B. lactofermentum $15\left(2 \times 10^{8} \mathrm{c.f} . \mathrm{u} . \mathrm{ml}^{-1}\right)$ was mixed with pBLA DNA (625 ng ml-1). (a) Dependence of transformation frequency (transformants per viable cell, $\square$ ) on field strength in the range 3.125 to $6.25 \mathrm{kV} \mathrm{cm}^{-1}$ ( $25 \mu \mathrm{F}$ capacitor) was determined using the gene pulser apparatus (Bio-Rad) with electrodes of $0.4 \mathrm{~cm}$ gap $(0.8 \mathrm{ml}$ cell suspension). (b) High voltage densities were achieved using the Pulse Controller unit, electroporation cuvettes with a $0.2 \mathrm{~cm}$ interelectrode distance ( $40 \mu \mathrm{l}$ cell suspension) and field strengths between 6.25 and $12.5 \mathrm{kV} \mathrm{cm}^{-1}(25 \mu \mathrm{F}$ capacitor). The transformation frequency $(\square)$ and the survival $(\bullet)$ are shown. 
Table 1. Effect of cell concentration on transformation

pBLA (500 ng) was added to $0.8 \mathrm{ml}$ of a suspension of $B$. lactofermentum $15\left(1.0 \times 10^{8}\right.$ to $\left.3 \times 10^{9} \mathrm{c} . \mathrm{f} . \mathrm{u} . \mathrm{ml}^{-1}\right)$. The cells were pulsed at $6.25 \mathrm{kV} \mathrm{cm}^{-1}(25 \mu \mathrm{F}$ capacitor). Transformants were selected on a medium containing kanamycin $\left(25 \mu \mathrm{g} \mathrm{ml}^{-1}\right)$. The frequency (transformants per viable cell) and the transformation efficiency (transformants per $\mu \mathrm{g}$ of DNA) were determined.

\begin{tabular}{cccc}
\hline \hline C.f.u. $\mathrm{ml}^{-1}(x)$ & $\begin{array}{c}\text { Transformants } \\
\mathrm{ml}^{-1}(y)\end{array}$ & $\begin{array}{c}\text { Transformation } \\
\text { frequency }(y / x)\end{array}$ & $\begin{array}{c}\text { Transformation } \\
\text { efficiency }\end{array}$ \\
\hline $1.0 \times 10^{8}$ & $1.5 \times 10^{4}$ & $1.5 \times 10^{-4}$ & $2.4 \times 10^{4}$ \\
$4.0 \times 10^{8}$ & $1.0 \times 10^{5}$ & $2.5 \times 10^{-4}$ & $1.6 \times 10^{5}$ \\
$3.0 \times 10^{9}$ & $5.0 \times 10^{5}$ & $1.7 \times 10^{-4}$ & $8.0 \times 10^{5}$ \\
\hline
\end{tabular}

\section{Electrotransformation of cells pre-treated with ampicillin}

The experimental conditions established to transform $B$. lactofermentum 15 gave poor results for the parental strain 180 and strain 10 . For these refractory strains, the intact cell wall may hinder DNA uptake. Partial disorganization of the cell wall, by pre-treatment with sublethal concentrations of a $\beta$-lactam antibiotic, could render refractory strains electrotransformable. Indeed, it has been reported that protoplast transformation also required such pretreatment associated with a lysozyme treatment (Katsumata et al., 1984; Yeh et al., 1985; Yoshihama et al., 1985).

Exponentially growing cells were treated with different concentrations of ampicillin for $90 \mathrm{~min}$ (one doubling time), then electrotransformed as described in Methods. The two refractory strains could be transformed only when ampicillin was added to the cell culture (Fig. $3 a, b$ ). This pretreatment also slightly improved the transformability of strain 15 (Fig. 3c). However, the level of transformation obtained for the two refractory strains was never as high as that for strain 15. The optimal concentration of ampicillin was 0.5 to $1.5 \mu \mathrm{g} \mathrm{ml}^{-1}$. With ampicillin treatment and without electric pulse no transformants could be detected.

\section{Evidence for plasmid DNA penetration during the electric pulse}

To investigate whether cells remain permeable to DNA after the electric pulse, DNAase $\left(8 \mu \mathrm{g} \mathrm{ml}^{-1}\right)$ was added to the samples $\left(2 \times 10^{8}\right.$ c.f.u. $\left.\mathrm{ml}^{-1}, 875 \mathrm{ng} \mathrm{DNA} \mathrm{ml}^{-1}\right)$ at different stages of electrotransformation. DNAase completely inhibited transformation when added before the electric pulse, but had no inhibitory effect $\left(1.4 \times 10^{4}\right.$ transformants $\mathrm{ml}^{-1}$ obtained) when added immediately after the pulse. This shows that DNA uptake is very fast and suggests that DNA penetration is concomitant with the electric pulse.
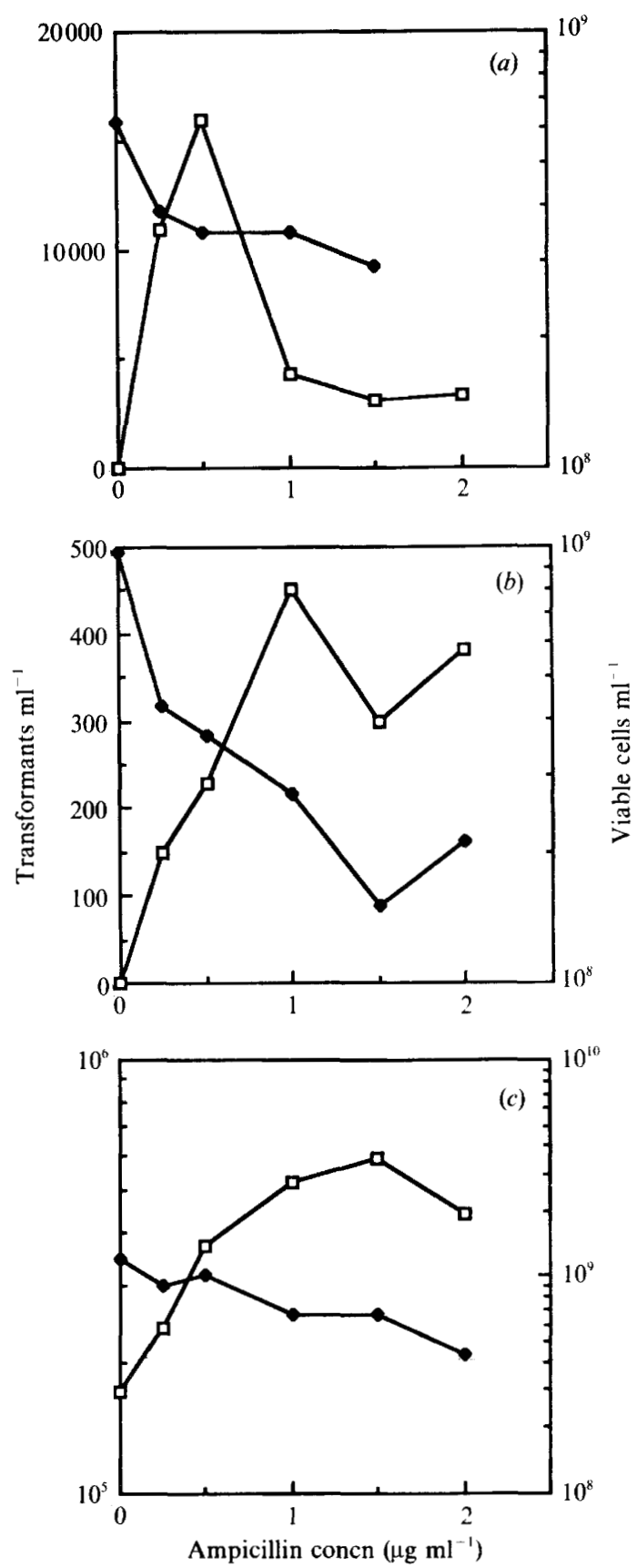

Fig. 3. Electrotransformation of cells pretreated with ampicillin. DNA $(500 \mathrm{ng})$ was added to $0.8 \mathrm{ml}$ of cell suspension of $B$. lactofermentum strain $180(a), 10(b)$ or $15(c)$. The samples were pulsed at $6.25 \mathrm{kV} \mathrm{cm}^{-1}$ $(25 \mu \mathrm{F}$ capacitor) and the numbers of transformants $(\square)$ and viable cells (O) were determined.

\section{Electrotransformation of cells by different structural} forms of plasmid DNA

pBLA was linearized with restriction enzyme Pst $\mathrm{I}$, which cuts within the $\beta$-lactamase gene (Fig. 1). Linear fragments and open-circle forms were purified by 
Table 2. Influence of electric field on the restrictionmodification system

The transformation efficiencies (transformants per $\mu \mathrm{g}$ of DNA) of $B$. lactofermentum strains $15\left(\mathrm{r}^{-} \mathrm{m}^{-}\right)$and $180\left(\mathrm{r}^{+} \mathrm{m}^{+}\right)$with $\mathrm{pBLA}$ $(500 \mathrm{ng})$ isolated from either $E$. coli or $B$. lactofermentum were determined. For electrotransformation, the cell suspensions of $B$. lactofermentum strains $180\left(2 \times 10^{7}\right.$ c.f.u. $\left.\mathrm{ml}^{-1}\right)$ and $15\left(3 \times 10^{7}\right.$ c.f.u. $\left.\mathrm{ml}^{-1}\right)$ were pretreated with ampicillin $\left(1 \mu \mathrm{g} \mathrm{m}^{-1}\right)$ and concentrated 10 -fold before the pulse $\left(6.25 \mathrm{kV} \mathrm{cm}^{-1}, 25 \mu \mathrm{F}\right.$ capacitor).

\begin{tabular}{lcc}
\hline \hline & \multicolumn{2}{c}{$\begin{array}{c}\text { Transformation efficiency } \\
\text { pBLA from: }\end{array}$} \\
\cline { 2 - 3 } \multicolumn{1}{c}{ Recipient } & B. lactofermentum & E. coli \\
\hline $\begin{array}{l}\text { B. lactofermentum } \\
180\left(\mathrm{r}^{+} \mathrm{m}^{+}\right)\end{array}$ & $1.0 \times 10^{4}$ & $1.5 \times 10^{3}$ \\
$\begin{array}{l}\text { B. lactofermentum } \\
15\left(\mathrm{r}^{-} \mathrm{m}^{-}\right)\end{array}$ & $1.6 \times 10^{6}$ & $3.0 \times 10^{5}$ \\
\hline \hline
\end{tabular}

electroelution and used for electrotransformation. Denatured DNA samples were also prepared. The open-circle forms transformed efficiently $\left(2.2 \times 10^{5}\right.$ transformants per $\mu$ g DNA). About the same efficiency was obtained with the native pBLA DNA. However, the use of either linear or denatured forms of pBLA decreased the transformation efficiency (respectively $2.0 \times 10^{3}$ and $3.4 \times 10^{4}$ transformants per $\mu \mathrm{g}$ DNA). Presumably either the uptake of linear or denatured DNA is reduced or these forms are degraded readily after entry.

\section{Influence of electric field on the restriction-modification system}

We studied the electrotransformation of strains 180 $\left(\mathrm{r}^{+} \mathrm{m}^{+}\right)$and $15\left(\mathrm{r}^{-} \mathrm{m}^{-}\right)$by pBLA isolated from either $E$. coli or $B$. lactofermentum. Table 2 shows that the transformation efficiency of strain 180 using heterologous plasmid DNA was about 10 -fold lower than that obtained using homologous plasmid DNA. A similar difference was found when strain 15 was transformed using homologous and heterologous plasmid DNA. In contrast, with the PEG-mediated-transformation procedure, heterologous transformation was reduced 900 -fold as compared with homologous transformation for $B$. lactofermentum strain 180 and only 10 -fold for strain 15 Bonnassie et al., 1990). Thus restriction by $B$. lactofermentum 180, which has been lost in the $\mathrm{r}^{-} \mathrm{m}^{-}$strain 15 , could not be detected by electrotransformation.

\section{Discussion}

We have shown that plasmid DNA can be efficiently introduced into intact cells of $B$. lactofermentum by electrotransformation. This method is more rapid and gives a more reproducible transformation frequency (transformants per viable cell) than conventional procedures, which require the conversion of cells to protoplasts followed by a regeneration step.

The data obtained with $B$. lactofermentum $15\left(\mathrm{r}^{-} \mathrm{m}^{-}\right)$ indicate that an initial electric field strength of $6.25 \mathrm{kV} \mathrm{cm}^{-1}$, with a capacitance of $25 \mu \mathrm{F}$, gives an efficiency of $4.8 \times 10^{4}$ transformants per $\mu \mathrm{g}$ DNA for a cell concentration of $2 \times 10^{8}$ c.f.u. $\mathrm{ml}^{-1}$. This efficiency can be increased with cell concentration up to $8 \times 10^{5}$ transformants per $\mu \mathrm{g}$ DNA. Other parameters such as growth conditions or electroporation buffer composition could be important in electrotransformation, but they were not analysed in this work. MacNeil (1987) observed a relationship between the transformation frequency and the lysis of protoplasts. In contrast, as previously described by Miller et al. (1988), we found that lethality does not appear necessary to obtain efficient transformation in intact cells. This is supported by the fact that the greatest yield of transformants occurred when the survival rate was high. Our results indicate that electrotransformation is a process quite different from transformation via the development of natural competence; it does not require special conditions of growth and DNA uptake is extremely fast, as if DNA penetration were concomitant with the pulse. This suggests that the transport of DNA across the cell envelope occurs during the electric pulse.

Pre-treatment with ampicillin allowed electrotransformation of two recalcitrant $B$. lactofermentum strains, for which no transformants were obtained without pretreatment. Ampicillin, a member of the $\beta$-lactam family, partially disorganizes the cell wall. Presumably the cell wall in these strains hindered DNA uptake during the electric pulse. At the concentrations used here, ampicillin does not lyse the cells, but seems to increase transformability. It is not known whether this is due to an increase in the fraction of transformable cells in the culture or to an increased probability of DNA uptake per viable cell. This ampicillin pre-treatment is a suitable and brief step for transforming some recalcitrant strains. However, the optimal conditions of ampicillin treatment will probably have to be carefully determined for each strain.

Restriction of heterologous DNA was not detected by electrotransformation. One explanation could be that DNA uptake mainly involves single-stranded DNA, which escapes restriction, but this is unlikely, since we showed that denatured DNA transforms sevenfold less efficiently than native DNA. The cellular localization of the restriction enzymes remains unknown. It might be that transient alteration of these enzymes could result from a rise in temperature due to the Joule heating effect 
at high voltages. Indeed, in $E$. coli, inhibition of restriction by a temperature shock was observed by Schell \& Glover (1966). However, this observation cannot be extended to other corynebacteria, since Bonamy et al. (1990) found that restriction was not inactivated by electrotransformation in Corynebacterium glutamicum and Corynebacterium melassecola. Restriction systems are inhibited by electroporation in Streptococcus pneumoniae (Bonnassie et al., 1989) and Lactococcus lactis (Langella \& Chopin, 1989). It is possible that the inhibition of restriction by electroporation depends on the restriction system itself.

In conclusion, electrotransformation could be a useful method for research in genetic engineering of $B$. lactofermentum.

This investigation was supported by a grant awarded by Organibio (CHVP program) and Ministère de la Recherche et de la Technologie. B. Daucé-Léreverend and M. P. Ayrolles participated in the isolation and analysis of pBL1.We would like to thank A. Deschamp for the Brevibacterium lactofermentum strain, P. Courvalin for plasmid pAT21-1 and J. Tessié for using Jouan apparatus. We are grateful to $\mathrm{J}$. Coveney for critical reading of the manuscript.

\section{References}

Avery, O. T., MCLeod, C. M. \& MCCARTY, M. (1944). Studies on the chemical nature of the substance inducing transformation of pneumococcal types. Induction of transformation by a DNA fraction isolated from pneumococcus type III. Journal of Experimental Medecine 89, 137-158.

BiBB, M. J., WARD, J. M. \& HoPwOOD, D. A. (1978). Transformation of plasmid DNA into Streptomyces at high frequency. Nature, London 274, 398-400.

Bonamy, C., Guyonyarch, A., Reyes, O., David, F. \& Leblond, G. (1990). Interspecies electro-transformation in corynebacteria. FEMS Microbiology Letters 66, 263-270.

Bonnassie, S., Gasc, A. M. \& SiCard, A. M. (1989). Transformation by electroporation of two gram-positive bacteria: Streptococcus pneumoniae and Brevibacterium lactofermentum. In Genetic Transformation and Expression, pp. 71-75. Edited by L. O. Butler, C. Harwood \& B. E. B. Moseley. Hampshire: Intercept.

Bonnassie, S., Oreglia, J., Trautwelter, A. \& Sicard, A. M. (1990). Isolation and characterization of a restriction and modification deficient mutant of Brevibacterium lactofermentum. FEMS Microbiology Letters (in the Press).
Chang, S. \& Cohen, S. N. (1979). High frequency transformation of Bacillus subtilis protoplasts by plasmid DNA. Molecular and General Genetics 168, 111-115.

Chassy, B. M., Mercenier, A. \& Flickinger, J. (1988). Transformation of bacteria by electroporation. Trends in Biotechnology 6, 303309.

Dower, W. J., Miller, J. F. \& Ragsdale, C. W. (1988). High efficiency transformation of Escherichia coli by high voltage electroporation. Nucleic Acids Research 16, 6127-6145.

IsH-HorowICZ, D. \& BURKE, J. F. (1981). Rapid and efficient cosmid vector cloning. Nucleic Acids Research 9, 2989-2998.

Katsumata, R., Ozaki, A., OKa, T. \& Furuya, A. (1984). Protoplast transformation of glutamate producing bacteria with plasmid DNA. Journal of Bacteriology 159, 306-311.

LANGELla, P. \& CHOPIN, A. (1989). Effect of restriction-modification systems on transfer of foreign DNA in Lactococcus lactis subsp. lactis. FEMS Microbiology Letters 59, 301-306.

MACNEIL, D. J. (1987). Introduction of plasmid DNA into Streptomyces lividans by electroporation. FEMS Microbiology Letters 42 , 239-244.

MANDEL, M. \& HIGA, A. (1970). Calcium-dependent bacteriophage DNA infection. Journal of Molecular Biology 53, 159-162.

Maniatis, T., Fritsch, E. F. \& Sambrook, J. (1982). Molecular Cloning, a Laboratory Manual. Cold Spring Harbor, NY: Cold Spring Harbor Laboratory.

MilLER, J. F., Dower, W. J. \& ToMPKINS, L. S. (1988). High-voltage electroporation of bacteria : genetic transformation of Campylobacter jejuni with plasmid DNA. Proceedings of the National Academy of Sciences of the United States of America 85, 856-860.

Ozaki, A., Katsumata, R., OKa, T. \& Furuya, A. (1984). Functional expression of the genes of Escherichia coli in gram-positive Corynebacterium glutamicum. Molecular and General Genetics 196, 175-178.

SCHELl, J. \& Glover, S. W. (1966). The effect of heat on hostcontrolled restriction of phage $\lambda$ in Escherichia coli $\mathrm{K}(\mathrm{P} 1)$. Journal of General Microbiology 45, 61-72.

Trieu-Cuot, P. \& Courvalin, P. (1983). Nucleotide sequence of the Streptococcus faecalis plasmid gene encoding the $3^{\prime} 5^{\prime \prime}$-aminoglycoside phosphotransferase type III. Gene 23, 331-341.

WIRTH, R., FrIESENEGGER, A. \& FIEDLER, S. (1989). Transformation of various species of gram-negative bacteria belonging to 11 different genera by electroporation. Molecular and General Genetics 216, 175177.

Wolf, H., Puhler, A. \& Neumann, E. (1989). Electrotransformation of intact and osmotically sensitive cells of Corynebacterium glutamicum. Applied Microbiology and Biotechnology 30, 283-289.

Yeh, P., Oreglia, J. \& Sicard, A. M. (1985). Transfection of Corynebacterium lilium protoplasts. Journal of General Microbiology 131, 3179-3183.

Yeh, P., Oreglia, J., Prevots, F. \& Sicard, A. M. (1986). A shuttle vector system for Brevibacterium lactofermentum. Gene 47, 301-306.

Yoshimama, M., Higashiro, K., Rao, E. A., AKedo, M., Shanabruch, W. G., Follettie, M. T., Walker, G. C. \& Sinskey, A. J. (1985). Cloning vector for Corynebacterium glutamicum. Journal of Bacteriology 162, 591-597. 